The nose is also quite perfect, and inclined to be rather broad and flat than thin and protruding. The malar bones are very prominent. The lips are thin and stiff, and the tongue is dried and solid. Two central incisores and one canine of the superior maxillary are gone, and several other teeth are badly caried.

Here, again, the hair and dried integument prevent absolutely accurate cranial measurements. The skull measures: circumference, 503 millimetres; length, occipito-frontal, I66 mm. ; breadth, bi-bregmatic, I 28 $\mathrm{mm}$.; breadth of frontal, I03 $\mathrm{mm}$; ; height, $132 \mathrm{~mm}$.; facial angle, $69^{\circ}$.

This skull presents a large forehead and well-developed reasoning powers. It is very rare to find so good a head among Indian women of to-day.

The little boy seems to have been about seven years old. The little fellow had been enveloped in his burial shrouds the same as the larger bodies-hands crossed on the chest, knees doubled on the breast, and the head inclined forward. All the bodies were probably tied in this position when placed in the cave. The body is about three feet tall, and weighs now only three pounds. The same general characteristics as to skin, tissues, bones, \&c., that were observed in the preceding bodies, may also be seen here. The head is well developed for a boy of his age. The hair has been broken off near the scalp. Only the cartilaginous parts of the ears remain. There is the same contour of face-flat nose, high cheek-bones, nutward obliquity of the eyes, \&c. The upper and lower incisores and canine of the temporary or milk teeth are gone, and the permanent set coming at their roots in the alveolar processes.

The two anterior molars of the superior maxillary are just appearing through the alveolar processes, establishing the age with tolerable accuracy at about seven years.

In circumference the skull measures 440 millimetres; length, occipito-frontal, $146 \mathrm{~mm}$. ; breadth, bi-bregmatic, I $20 \mathrm{~mm}$. ; breadth of frontal, $60 \mathrm{~mm}$. ; height, II $4 \mathrm{~mm}$. ; facial angle, $7 \mathrm{I}^{\circ}$.

A considerable part of the burial shroud remains about the body yet. The major portion of it is cotton fabric, firmly secured around the body by a stronger cord, made of braided hair.

The little girl may have been about fourteen to eighteen months of age. She weigbs only a pound and a half. She has been enveloped in an animal's skin, the better to protect the tender frame. Both feet are gone, and the tibia and fibulæ protrude through the skin. The four upper and four lower incisores, with the corresponding canine teeth, have made their appearance, showing the child to be about fourteen to eighteen months old. Otherwise the same features are noticeable in this as in the proceding figures.

It would appear that the group of four belong to one family, and that they were buried by friends, and hermetically sealed in this cave for fear of some real or imaginary foe. It may have been at the time of the Spanish invasion, or it may have been during the warlike times anterior to this date, when the Aztec confederation was warring with the Toltec people.

From their physical and mental developments the race seems to have been a superior one.

The facial features observed in these bodies are not those found in that locality now. The cranial configurations and physical appearances would rather favour Aztec lineaments than those of the Indian of to-day. The fine dark brown hair is certainly not Indian, nor do the small hands and feet bear much resemblance to the huge hands and feet we see on the Indians now living.

The fabrics found on the bodies, forming the burial shrouds, are chiefly composed of cotton, hair, hide, grasses, and the bark of willows. The cotton is twisted and coarsely woven, each thread being from a half to one millimetre in diameter. The hair is treated in like manner occasionally, although usually it is braided with three or four divisions in each cord. Frequently we find strong strands made of strips of hide covered with willow bark.

Although the weaving of this interesting people is that known as the "plain" process-that is, where the weft passes alternately under and over the threads of the warp, producing more or less open mesh cloth-yet considerable skill and ingenuity were observed in the manufacturing of their blankets, mats, and ornamental cloths, which were frequently interwoven with beads and coloured threads, presenting various designs. Grasses and straws were also woven into mats and cloths, which were of great durability. The skins of animals were also used for clothing purposes.

\section{THE PHILIPPINE ISLANDS.}

M R. WALLACE, in his great work "The Geographical Distribution of Animals," divides the Oriental or Indian region of Mr. Sclater into four subregions, of which Java, Sumatra, Malacca, Borneo, and the Philippine Islands form one, which he calls the IndoMalayan. In his discussion of the Indo-Malayan subregion Mr. Wallace recognizes several subdivisions of it, and treats of the Philippine Islands as one of the most important of these. Though acknowledging the existence of divisions of his sub-regions, he failed to give them technical names, as being at that time uncalled for.

The purpose of this paper is to show that the Philippines themselves are separated into several distinct zoological divisions, and it seems therefore necessary for their study to give technical names to the primary and secondary divisions of the already recognized sub-regions. The terms province and sub-province seem least objectionable, and will be made use of, the Philippine Islands thus forming one of the provinces of the IndoMalayan sub-region, and the divisions of the group itself sub-provinces.

The zoological province of the Philippines is co-extensive with the political division of the same name, with perhaps the exception of the islands of Sulu and Tawi Tawi, which lie between the Philippines and Borneo, but are claimed by the Spanish.

The sub-provinces proposed are-first, the Northern Philippines, consisting of Luzon and Marinduque, and a number of other small islands about Luzon ; second, Mindoro; third, the Central Philippines, made up of the islands of Panay, Negros, Guimaras, Zebu, Bohol, and Masbate ; fourth, the Eastern Philippines, comprising the islands of Samar and Leyte; fifth, the Southern Philippines, embracing the great island of Mindanao, with Basilau, and perhaps Sulu; and sixth, the Western Philippines, consisting of the islands of Paragua or Palawan, and Balabac.

The geographical positions of these sub-provinces are so far fortunate, that these names show their relations to each other very closely, as may be seen by consulting a map of the archipelago.

Of the sub-provinces, the Western Philippines, made up of Paragua and Balabac, and perhaps the Calamines, is of most importance, its animal life being much more closely allied to that of Borneo than that of any other sub-province of the group. This is especially noticeable in its mammals, of which it possesses, in common with Borneo, the genera Tragulus, Tupaia, and Manis, which are apparently absent from the rest of the archipelago. Of Bornean genera of birds, not found elsewhere in the group, Iora, Criniger, Polyplectron, Tiga, and Batrachostomus, are examples. This sub-province has evidently received a large part of its fauna from North Borneo, through Balabac, at a comparatively recent date, and 
since its separation, on the north, from the rest of the Philippines, so that these genera have not flowed over into Mindoro and Luzon. In addition to these apparently late arrivals from Bornec, the sub-province possesses a large number of peculiarly Philippine birds and mammals, which show it to be an integral part of the province.

The rest of the Philippines would seem to have received their Malayan fauna at another time, and by the other way of Sulu and Mindanao. They possess the mammalian genera, Galeopithecus, Tarsius, and Cervus, which are apparently wanting in the western sub province, and the genera Macacus, Sus, Viverra, Paradoxurus, and Sciurus in common with it. Of birds, the genera Loriculus, Cyclopsitta, Buceros, and Penelopides are examples of forms which are more or less generally distributed over the archipelago outside of the western sub-province.

The grounds for dividing the Philippines east of Paragua into sub-provinces are, to a great extent, based upon species, and especially upon the existence in each of representative forms of the genera Loriculus, Buceros, Penelopides, Pitta, Chrysocolaptes, Dicaum, Cinnyris, \&c. The hornbills form perhaps the most striking example of this distribution of representative species. Of the eleven species of hornbills obtained in the islands, the western sub-province has one, the southern three, the central two, the eastern two, Mindoro one, and the northern sub-province two, and we have found no case of a single species occupying more than one sub-province, or of more than one species of a genus in a single sub-province. The genus Chrysocolaptes of woodpeckers is also noticeable, each sub-province possessing its own species, with the exception of Mindoro, which lacks the genus altogether. The genus Loriculus of the parrots is of the same character. Of other animals than birds, the genus Sciurus of mammals, and Draco, the flying lizards, seem to have representative species in each sub-province, and the land-mollusks are probably distributed in the same way.

The above examples are a few that come to mind before a careful study of our collections has been made, and they do not by any means show all the reasons for the conclusions arrived at. These are the results rather of the general observations of five careful men who have been collecting and studying in the Philippines during the last year. During this time we have visited and collected in fifteen islands of the group, and these the largest and most important. I am satisfied that the study of our collections with the aid of the libraries and collections at home, will only strengthen the conclusions of this paper. It may be necessary to make the so-called western subprovince of more importance in the arrangement, but the non-existence in nature of exactly equivalent divisions of any kind is well recognized.

It is hoped that our work may aid in untangling some of those puzzles in which students of Philippine zoology have found themselves involved, and that it will also add considerably to the sum of knowledge concerning this, as yet, imperfectly known corner of the earth.

Manilla, July 2, 1888 .

$$
\text { J. B. STEERE. }
$$

\section{BAROMETRIC OSCILLATIONS.}

THE following account of what appears to have been the passing of H.M. surveying-ship Egeria through the embryo of a cyclonic disturbance, has been received from Captain Aldrich, of that ship.

Admiralty, August I.

$$
\text { W. J. L. WHARTON. }
$$

$$
\text { H.M.S. "Egeria," at sea, June 6, I } 888 .
$$

I send the following extract from my journal, which may possibly be of interest to meteorologists :-

"May 3I._ . . . There has been a swell from the southwest during the day. The lower clouds come from be

eastward, while the upper ones are from the westward. This appears to be a common occurrence in this locality.

"o June I.-Weather cloudy all night, and wind-force $2 \cdot 3$, gradually veering, till at $3.30 \mathrm{a} . \mathrm{m}$. it was to the northward of east. Barometer rising slowly. At 6 a.m. the wind shifted to the north-east in a rain-squall ; nimbus, and a generally dark appearance in the sky. At 7 a.m. the officer of the watch sent down to tell me the barometer had fallen 0.12 of an inch in the previous hour. I was about to commence dressing at the time, but, hurry ing on my things, I looked at the aneroid in my forecabin, and found the report correct. I immediately reset the aneroid and went on deck, and although there were no signs of any forthcoming disturbance, the light sails and mainsail were taken in. At 7.20 I had the barometer again read, when it was reported to have risen nearly ${ }_{10}^{1}$ inch in the twenty minutes. I went down immediately, and found by the aneroid this jump had taken place. During this time there was no change in the weather, though the wind drew to the north-north-east."

Now there is no doubt whatever that the barometer went up 9/100 in twenty minutes. Of course, it cannot be known to an hour when it previously dropped 12 , as the instrument was not read between 6 a.m. and 7 a.m., and the drop may possibly have been greater even, and also may have taken place as suddenly as it rose afterwards. There is no doubt that some extraordinary disturbance of the atmosphere took place, though beyond the foregoing observations we neither saw nor experienced anything of it. The following are the actual readings of the mercurial barometer :--

$\begin{array}{llr}\text { a m. } & & \text { Inches. } \\ 6 & \ldots & 30.170 \\ 7 & \ldots & 30.050 \\ 7.20 & \ldots & 30.144 \\ 7.30 & \ldots & 30.154 \\ 7.45 & \ldots & 30.186 \\ 8 & \ldots & 30.186 \\ 9 & \ldots & 30.200\end{array}$
Position.
$24^{\circ} \mathrm{O} 4 \mathrm{~S}$
Long. $179^{\circ} 04 \mathrm{~W}$.

PELHAM ALDRICH.

\section{NOTES.}

THE following is the list of names recommended by the President and Council of the Royal Society for election into the Council for the year 1889 , at the forthcoming anniversary meeting on the 3oth inst. :--President: Prof. George Gabriel Stokes. Treasurer: Dr. John Evans. Secretaries: Prof. Michael Foster and Lord Rayleigh. Foreign Secretary : Prof. Alexander William Williamson. Other Members of the Council: Prof. Henry Edward Armstrong, Henry Bowman Brady, Charles Baron Clarke, Dr. William Huggins, John Whitaker Fulke, Prof. John W. Judd, Dr. Edward Emanuel Klein, Prof. E. Ray Lankester, Prof. Herbert McLeod, Sir James Paget, Bart., William Pole, William Henry Preece, Sir Henry E. Roscoe, Dr. Edward John Routh, Prof. Arthur William Ruicker, and Captain William James Lloyd Wharton, R.N.

The Pasteur Institute, Paris, is to be opened on the $13^{\text {th }}$ inst., in presence of numerous delegates of the French Aca. demies of Science and of Medicine, and of the Medical and Scientific Faculties. President Carnot will perhaps be present.

WE regret to announce the death of the well-known geologist, Dr. Theodor Kjerulf, Professor at the University of Chri-tiania, and Director of the Geological Survey of Norway. He died at Christiania on October 25, at the age of sixty-three. He received his appointment as Professor in 1858 , and since that time has made many important contributions to geological science. 